\title{
Kin discrimination in tadpoles of Hylarana temporalis (Anura: Ranidae) and Sphaerotheca breviceps (Anura: Dicroglossidae): influence of hydroperiod and social habits
}

\author{
Amrapali P. Rajput ${ }^{1}$, Srinivas K. Saidapur ${ }^{1}$, and Bhagyashri A. Shanbhag ${ }^{1,2}$ \\ ${ }^{1}$ Department of Zoology, Karnatak University, Dharwad 580 003, India. \\ ${ }^{2}$ Current address: INSA Senior Scientist, Department of Marine Biology, Karnatak University Post-Graduate Centre, Kodibag, \\ Karwar-581 303, India. E-mail: bhagyashrishanbhag@gmail.com.
}

\begin{abstract}
Kin discrimination in tadpoles of Hylarana temporalis (Anura: Ranidae) and Sphaerotheca breviceps (Anura: Dicroglossidae): influence of hydroperiod and social habits. Kin discrimination ability was studied in tadpoles of Hylarana temporalis and Sphaerotheca breviceps, which live in two distinctly different habitats; the former shows social aggregation and the latter live scattered. Early in development, tadpoles of $H$. temporalis are found in small aggregations in the streams of Western Ghats but in later stages they are generally seen in isolated pools cut off from the main channel following drying up of the stream. Sphaerotheca breviceps breed during south-west monsoons in rain-filled puddles and its tadpoles are always found scattered. We hypothesized that the tadpoles living in aggregation exhibit kin discrimination while those not living in aggregation may not exhibit kin discrimination. Further, tadpoles that face desiccation threat may also not exhibit kin discrimination behavior. Tests were conducted on tadpoles of the above two species at two developmental stages (Gosner Stages 28-30 and 34-36) to reveal their association choice with sibs and non-sibs. Tadpoles of H. temporalis associated with both familiar (reared with sibs) and unfamiliar (reared in isolation) sibs in early but not in later stages of development. Tadpoles of $S$. breviceps showed no association preference with sibs (familiar or unfamiliar) in both early and later stages. The findings on H. temporalis suggest that kin discrimination between sib from non-sib may be beneficial during early stages of development that takes place in flowing streams and it may be less important in later stages of development taking place in pools of water bodies that face
\end{abstract}

Received 26 June 2014.

Accepted 2 December 2014.

Distributed December 2014. 
desiccation. Absence of kin recognition in S. breviceps is associated with their lack of natural aggregation and perennial desiccation threat of the ephemeral ponds. We suggest that kin discrimination behavior in tadpoles is related to their social habits and hydroperiod of their habitat.

Keywords: aggregative behavior, desiccation, ontogeny, streams, rain-filled puddles.

\begin{abstract}
Resumo
Discriminação de parentesco em girinos de Hylarana temporalis (Anura: Ranidae) e Sphaerotheca breviceps (Anura: Dicroglossidae): influência do hidroperíodo e dos hábitos sociais. A habilidade de discriminação de parentesco foi estudada em girinos de Hylarana temporalis e Sphaerotheca breviceps, que vivem em dois diferentes habitats; a primeira espécie apresenta agregação social e a segunda vive dispersa. No início do desenvolvimento, os girinos de H. temporalis são encontrados em pequenas agregações nos riachos dos Ghats Ocidentais, mas em estágios avançados são geralmente vistos em poças isoladas associadas ao leito principal após a seca do riacho. Sphaerotheca breviceps reproduz-se durante as monções de sudoeste em lagoas formadas pelas chuvas, e seus girinos são sempre encontrados dispersos. Trabalhamos com a hipótese de que os girinos que vivem agregados exibem discriminação de parentesco, enquanto aqueles que não formam agregações podem não exibir essa discriminação. Além disso, os girinos que enfrentam ameaça de dessecamento podem também não exibir comportamento de discriminação de parentesco. Foram conduzidos testes com girinos das duas espécies acima em dois estágios de desenvolvimento (Gosner 28-30 e 34-36) para descobrir sua escolha de associação com irmãos ou não-irmãos. Os girinos de $H$. temporalis associaram-se tanto com irmãos familiares (criados com irmãos) como irmãos não-familiares (criados em isolamento) nos estágios iniciais do desenvolvimento, mas não nos estágios finais. Os girinos de $S$. breviceps não mostraram preferência de associação com irmãos (familiares ou não) tanto nos estágios iniciais como nos finais. As descobertas relacionadas a $H$. temporalis sugerem que a discriminação de parentesco entre irmãos e não-irmãos pode ser benéfica durante os estágios iniciais do desenvolvimento que ocorre em riachos, e pode ser menos importante nos estágios finais do desenvolvimento em corpos d'água sujeitos ao dessecamento. A ausência do reconhecimento de parentesco em $S$. breviceps está associada à ausência de agregação natural e à ameaça de dessecamento de lagoas temporárias. Sugerimos que o comportamento de discriminação de parentesco em girinos está relacionado aos seus hábitos sociais e ao hidroperíodo de seu habitat.
\end{abstract}

Palavras-chave: comportamento de agregação, dessecamento, ontogenia, poças temporárias, riachos.

\section{Introduction}

The ability to discriminate kin from non-kin has been reported in many species of animals and also in some plants (Blaustein 1987, Blaustein and Waldman 1992, Pfennig and Sherman 1995, Holmes 2004, Dudley et al. 2013). Hamilton (1964a,b) opined that if all else is equal, individuals help relatives over nonrelatives when the benefit exceeds the cost in terms of genetic/inclusive fitness. Kin recognition benefits siblings through increased cooperation, contribution to uniform growth rates, increased vigilance for predators, and reduced competition for resources, thereby conferring inclusive fitness to the individuals of the sibling group (Waldman and Bateson 1989, Hepper 1991, Roche 1993, Blaustein and Walls 1995, Roberts 1996, Saidapur and Girish 2000, Mateo 2002, Ha et al. 2003).

Tadpoles are ideal for the study of kin discrimination since they occur in large numbers 
and generally remain confined to small areas until metamorphosis. Tadpoles living in ephemeral ponds often occur at high densities and live in unpredictable environments under the constant threat of desiccation. Studies on kin discrimination behavior in tadpoles show that some species discriminate sibs from non-sibs (Waldman and Adler 1979, Blaustein 1988, Pfennig et al. 1999, Saidapur and Girish 2000, Gramapurohit et al. 2006), while tadpoles of other species do not even recognize familiar sibs with whom they are reared (O'Hara and Blaustein 1988, Fishwild et al. 1990, Blaustein and Walls, 1995, Gutierrez-C. 2006, Rajput et al. 2011). Association preference with sibs persists throughout larval development in tadpoles of $R$. cascade (Blaustein et al. 1984) and B. melanostictus (Saidapur and Girish 2000), while tadpoles of $R$. aurora (Blaustein et al.1993) and B. scaber (Gramapurohit et al. 2006) lose kin discrimination ability in later stages of development. Thus, the kin discrimination behaviour of tadpoles varies among species.

It is generally believed that tadpoles living in aggregations possess kin discrimination abilities (Waldman and Adler 1979, Blaustein 1988, Blaustein and Waldman 1992, Roche 1993). Living in aggregation accrues benefits such as predator deterrence, reduced competition for resources, thermal advantages and improved growth rates (Blaustein and Waldman 1992, Roche 1993, Nicieza, 1999). In tadpoles living in aggregations associating preferentially with siblings could improve their overall fitness and, therefore kin recognition systems in such species are likely beneficial. In contrast, in species whose tadpoles do not interact with each other, kin discrimination ability has little opportunity to evolve (Blaustein and Waldman 1992). It is suggested that tadpoles that do not live in aggregation show no kin discrimination behavior (Fishwild et al. 1990, Gutierrez-C. 2006, Gray et al. 2009).

The effect of kinship on traits such as growth, development and behavior are often context dependent (Hokit et al. 1996, Hokit and Blaustein
1997, Harris et al. 2003, Pakkasmaa and Laurila 2004, Gramapurohit et al. 2008, Martin and Garnet 2013). For instance, in $R$. cascadae kinship interacts with other ecological factors to positively influence tadpole size and survival (Hokit and Blaustein 1997). In tadpoles of $R$. temporaria, positive effects of kinship on body size were seen only at low density (Pakkasmaa and Laurila 2004). In contrast, in B. scaber, positive effects of kinship on growth were observed when tadpoles were reared under crowded conditions (Gramapurohit et al. 2008). In larvae of the salamanders Hemidactylium scutatum and Ambystoma opacum, expression of kin discrimination is dependent upon social and environmental contexts (Hokit et al. 1996, Harris et al. 2003). Thus, these studies demonstrate kinship-mediated benefits expressed in certain habitat conditions rather than by presence of kin discrimination per se. A survey of literature on kin discrimination studies on tadpoles reveals that most of the work pertains to tadpoles dwelling in ponds or lentic waters (Reviews by Blaustein and Waldman 1992, Waldman 2005). However, relationship between hydroperiod of the habitat and kin discrimination behavior of tadpoles is not clearly brought out in these studies.

Tadpoles living in ephemeral ponds often live in unpredictable environments, facing a continuous threat of desiccation and increased conspecifics densities. The present study was undertaken to evaluate whether kin discrimination behavior in tadpoles of Hylarana temporalis (formerly known as Rana temporalis) and Sphaerotheca breviceps has any relationship with the social behavior and hydroperiod of breeding sites. Hylarana temporalis breed following monsoon conditions in streams of the Western Ghats while $S$. breviceps breed during monsoon conditions in rain-filled puddles that are not associated with streams. Tadpoles of $H$. temporalis live in small aggregations in gently flowing streams in early stages and in later stages they often occur in small pools of water that are isolated from the streams, upon stream drying. 
They take about 90-100 days to complete metamorphosis. Tadpoles of $S$. breviceps do not form aggregations throughout larval development and metamorphose quickly in 35-40 days in puddles that dry quickly if intermittent rains fail to occur. We hypothesized that the tadpoles that do not face the risk of desiccation and living in groups possess kin discrimination ability while those not staying in aggregation and completing metamorphosis under a constant threat of desiccation do not possess kin discrimination ability.

\section{Materials and Methods}

We collected five egg clutches of $H$. temporalis, spaced at a distances of 200-500 m from a gently flowing stream in Western Ghats $\left(15^{\circ} 04^{\prime} \mathrm{N}, 74^{\circ} 53^{\prime} \mathrm{E}\right)$, and collected four clutches of $S$. breviceps from rain-filled puddles spatially separated from each other by 200-300 m from Karnatak University Campus (15 $07^{\circ} \mathrm{N}, 75^{\circ} 03^{\prime}$ $\mathrm{E}$; area of campus - 303.51 ha). Soon after collection, egg clutches were brought to the laboratory and each clutch was placed in separate plastic tub $(42 \mathrm{~cm}$ diameter $\times 16 \mathrm{~cm}$ depth) containing $10 \mathrm{~L}$ aged tap water. Eggs of $H$. temporalis hatched after four days, while those of $S$. breviceps hatched within two days of collection. The resulting tadpoles were subjected to the following rearing regimes.

(i) Rearing with kin: 150 tadpoles (Gosner Stage 19) of each clutch of each species were reared in sibling groups in glass aquaria $(75 \times 45$ $\times 15 \mathrm{~cm}$ ) containing $25 \mathrm{~L}$ aged tap water.

(ii) Mixed rearing: glass aquaria $(75 \times 45 \times$ $15 \mathrm{~cm}$ ) were divided into two equal compartments by partitioning them with transparent perforated acrylic sheet having pore size of $1 \mathrm{~mm}$ diameter with $25 \mathrm{~L}$ aged tap water; 75 tadpoles (Stage 19) each from two parental lines were placed in opposite compartments.

(iii) Rearing in isolation: tadpoles of Stage 19 of a given parental line were randomly selected and reared individually in small plastic bowls (20 $\times 6 \mathrm{~cm}$ ) containing $0.5 \mathrm{~L}$ aged tap water.
Tadpoles of both species were given boiled spinach as food from Stage 25 onwards except during the trial period. Tadpoles between Stages 28-30 and 34-36 served as test subjects. Trials with Stages 34-36 tadpoles were conducted in $H$. temporalis 20 days following the completion of first set of trials (Stages 28-30) and 12 days following the completion of first set of trials in $S$. breviceps allowing them to reach the desired stages of development. Hylarana temporalis took 18-20 days and $S$. breviceps 10-12 days to attain Stage 34 from Stage 30.

\section{Design of the Association Test Tank and Experimental Setup}

A rectangular glass aquarium $(120 \times 30 \times$ $18 \mathrm{~cm}$ ) was used as a test tank. It was partitioned into three compartments using $2 \mathrm{~mm}$ thick perforated transparent acrylic sheets that were placed to create two $15 \mathrm{~cm}$ end compartments and a central compartment of $90 \mathrm{~cm}$ which served as the test arena. Two lines, $10 \mathrm{~cm}$ apart from the centre were drawn perpendicular to the long axis on the outer surface on the bottom of the test apparatus to mark the central zone for the release of test tadpoles. Areas between the zone of release and mesh partition constituted the test arena, while the end compartments served as stimulus zones A and B. For each trial a single test tadpole was introduced in an open-ended cylindrical mesh cage $(10 \mathrm{~cm}$ diameter) placed in the centre. The test tadpole was released after 10 min by gently lifting the mesh cage allowing it to familiarize with test arena. One minute following the release of tadpole, as a measure of association preference, time spent by the test tadpole and number of test tadpoles spending time in each zone was recorded for the subsequent $10 \mathrm{~min}$ using a stop watch. A test tadpole was used only once. End compartments housed stimulus tadpoles $(N=20)$ or with no stimulus tadpoles (stimulus blank) depending upon the experimental protocol. The test tank was thoroughly cleaned and filled with aged tap 
water before each trial. Stimulus tadpoles were renewed after 10 trials. Developmental stage and size of the test and stimulus tadpoles were always matched. The following tests were conducted on both species of tadpoles.

\section{(i) End-bias test}

In these trials, the end compartments did not house stimulus tadpoles. One hundred tadpoles, 20 from each of five parental lines in case of $H$. temporalis and 80 tadpoles, 20 from each of the four parental lines in case of $S$. breviceps were used as test tadpoles. Test tadpoles of stages 2830 and 34-36 were used.

\section{(ii) Tests with familiar sibs vs unfamiliar non-sibs}

One end compartment housed familiar sibs while the other end housed unfamiliar non-sibs and association choice tests were then conducted. Trials were conducted at early (28-30) and later (34-36) stages of development. A total of 150 trials (30 trials per parental line) in H. temporalis and 120 trials (30 trials per parental line) in $S$. breviceps were conducted.

Since tadpoles of $S$. breviceps did not exhibit any preference to associate with sibs in early or later stages, no further tests were conducted in this species. As the tadpoles of H. temporalis exhibited association preference with familiar sibs during their early stages (stages 28-30) but not in later stages, the following tests were conducted to know whether or not familiarity from the time of hatching is essential for kin discrimination using stage 28-30 tadpoles.

\section{(iii) Tests with unfamiliar sibs vs familiar non-sibs}

In these trials, one end of the test tank housed unfamiliar sibs and the other end housed familiar non-sibs. A total of 50 trials (10 trials per parental line) were performed. We hypothesized that if association of $H$. temporalis tadpoles with sibs is due to familiarity, then the test tadpole would preferentially associate with familiar nonsibs over unfamiliar sibs. Further, if prior familiarity is not the sole criteria for kin recognition, then the test tadpoles would prefer to associate with unfamiliar sibs rather than with familiar non-sibs.

To confirm whether or not familiarity with sibs is essential in the display of kin discrimination behavior the following sets of trials were conducted.

\section{(iv) Tests with unfamiliar sibs vs unfamiliar non-sibs}

In these trials, one end compartment housed unfamiliar sibs whereas the opposite end compartment housed unfamiliar non-sibs. Fifty trials were conducted using tadpoles reared in isolation (10 trials per parental line). It was hypothesized that in a situation where both sibs and non-sibs are unfamiliar, and if the test tadpoles associate with unfamiliar sibs, then kin discrimination behavior is independent of familiarity.

\section{(v) Tests with familiar vs unfamiliar sibs}

In these trials, one end compartment housed familiar sibs whereas the opposite end compartment housed unfamiliar sibs. Fifty trials were conducted using sib tadpoles reared together. It was hypothesized that if the test tadpoles associate equally with familiar and unfamiliar sibs then kin discrimination behavior is independent of familiarity.

\section{Statistical Analysis}

For each parental line, the number of test tadpoles spending majority of their time in each stimulus zone A and B was compared using binomial tests. Wilcoxon signed-ranks tests were used to analyse the time spent by test tadpoles (each parental line) in a zone either with sibs or non-sibs. We tested differences in the time spent near respective stimulus zones from a hypothetical random expected (300 s) under the null hypothesis that the test tadpole would spend equal amount of time in each zone. Therefore, only one score per animal was used in comparison 
with the expected mean not to violate the independence of data. All tests were two-tailed. Data were judged to be significant at $p<0.05$. Meta-analysis of different test groups of the same rearing type was performed using Fisher's procedure of combined probabilities from independent tests of significance for an overall result (Sokal and Rolf 1995). Fisher's procedure was applied on probabilities obtained from binomial tests and Wilcoxon signed-ranks tests.

\section{Results}

\section{Hylarana temporalis Tadpoles}

In end-bias tests, the test tadpoles of $H$. temporalis (Stages 28-30) showed random distribution in the test arena. They showed no bias towards any side of the test tank. In addition, the number of test tadpoles spending the majority of their time in zone A and B was also comparable (Table 1). Tests conducted to evaluate kin discrimination ability in $H$. temporalis tadpoles at Stage 28-30 of development showed that the test tadpoles spent most of the time near familiar sibs rather than near unfamiliar non-sibs (Table 2, Figure 1A). When test tadpoles were given a choice to associate with unfamiliar sibs versus familiar non-sibs, the majority of them spent most of their time near unfamiliar sibs rather than near familiar non-sibs (Table 3, Figure 1B). Also, significantly greater number of test tadpoles spent the majority of their time near unfamiliar sibs rather than near unfamiliar nonsibs (Table 4, Figure 1C). Further, the number of test tadpoles spending the majority of their time in the two stimulus zones housing either familiar or unfamiliar sibs was comparable (Table 5, Figure 1D). However, these tadpoles in their later stages of development (Stages 34-36) moved randomly in the test tank in trials with a choice to associate with familiar sibs or unfamiliar non-sibs; they spent comparable amount of time in both the zones as in the end-bias tests (Tables 6 and 7).

\section{Sphaerotheca breviceps Tadpoles}

In end-bias tests, tadpoles of $S$. breviceps showed random distribution in the test arena. They showed no bias towards any end of the test tank. The number of test tadpoles spending the majority of their time in zones A and B was also comparable (Tables 8 and 9). In association choice tests the test tadpoles spent comparable amount of time near sibs and non-sibs regardless of familiarity in both early (28-30) and later stages (34-36) of development (Tables 10 and 11).

Table 1. Distribution of tadpoles of Hylarana temporalis (Stage 28-30) in end-bias test. ${ }^{a}$ Compared using binomial

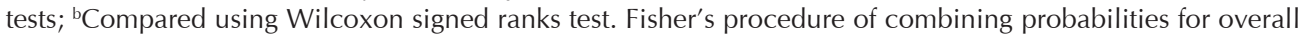
result: $-2 \sum \ln p=3.52, \chi_{(10)} p>0.05$ (number data); $-2 \sum \ln p=4.34, \chi_{(10)} p>0.05$ (time data).

\begin{tabular}{|c|c|c|c|c|}
\hline \multirow[t]{2}{*}{ Parental line } & \multicolumn{2}{|c|}{ Number spending most time near } & \multicolumn{2}{|c|}{ Time spent in zones ${ }^{b}($ Mean $\pm S E)$} \\
\hline & Zone A & Zone B & Zone A & Zone B \\
\hline$P_{1}$ & 10 & 10 & $308.75 \pm 37.80$ & $286.25 \pm 37.82$ \\
\hline $\mathrm{P}_{2}$ & 8 & 12 & $248.95 \pm 46.14$ & $351.05 \pm 46.14$ \\
\hline $\mathrm{P}_{3}$ & 11 & 9 & $294.55 \pm 45.83$ & $305.45 \pm 45.83$ \\
\hline $\mathrm{P}_{4}$ & 11 & 9 & $316.15 \pm 39.75$ & $283.85 \pm 39.75$ \\
\hline $\mathrm{P}_{5}$ & 12 & 8 & $301.00 \pm 28.33$ & $299.00 \pm 28.33$ \\
\hline
\end{tabular}



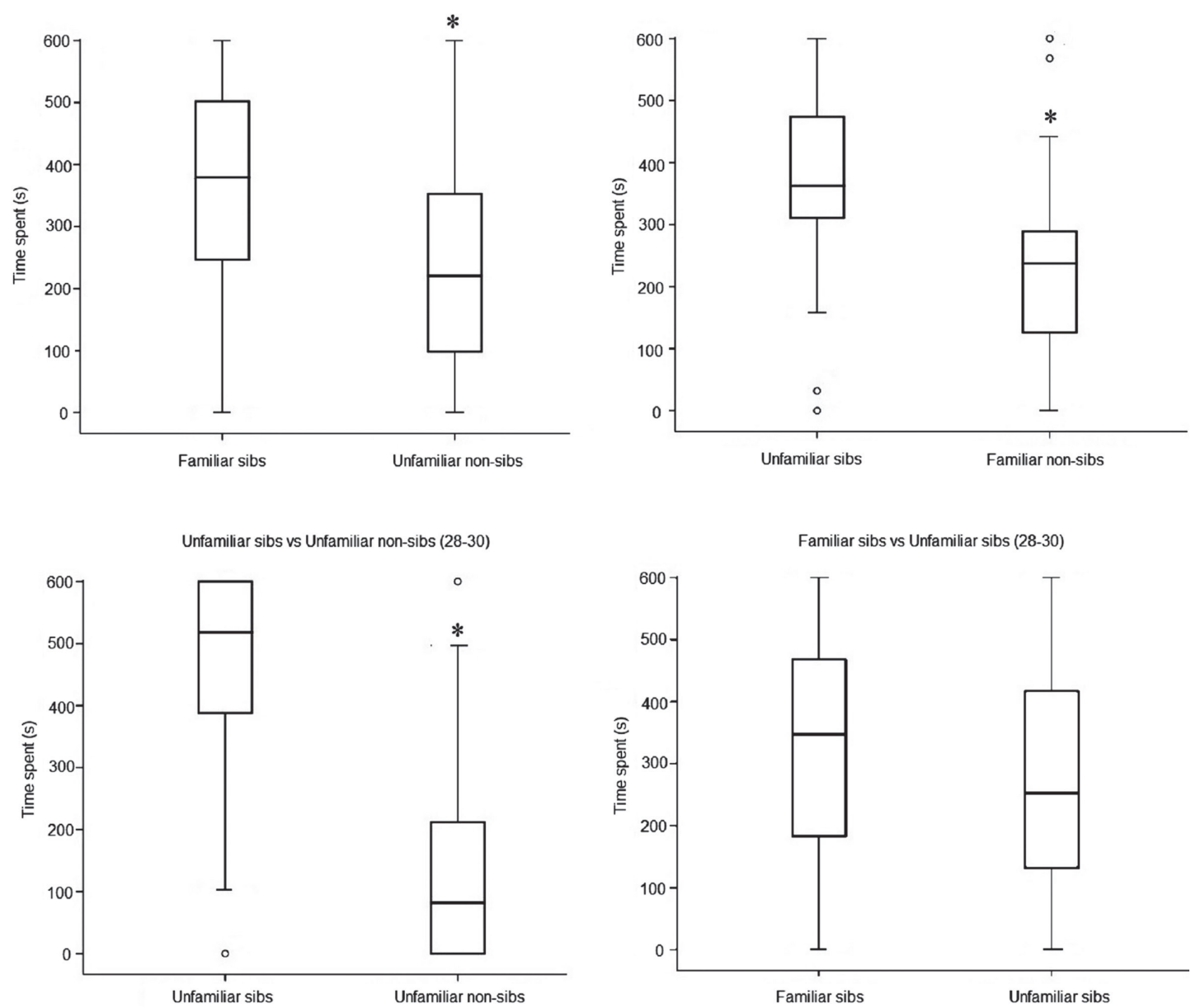

Figure 1. Box whisker plots showing association preference of Hylarana temporalis test tadpoles with respect to zones $\mathrm{A}$ and $\mathrm{B}$. Horizontal bars in the boxes represent medians, whiskers represent farthest data points that are not outliers, open circles above the whiskers represent outliers. The asterisks denote a significant difference in the time spent by the test tadpoles in the two zones.

\section{Discussion}

Living with kin groups is useful in foraging, reducing competition for resources, and enhancing chances of escape from predation (Hokit et al. 1996, Nicieza 1999, Harris et al. 2003, Martin and Garnett 2013). For example, kinship environment is known to promote uniform growth in the tadpoles of $H$. temporalis (Girish and Saidapur 1999, 2003) and reduce competitive effects on growth in Spea multiplicata (Martin and Garnett 2013). Because of the potential benefits of associating with kin, species of tadpoles living in aggregation in nature are postulated to exhibit kin discrimination behavior (Blaustein 1988, Blaustein and 
Table 2. Association preference of Hylarana temporalis tadpoles (Stage 28-30) with familiar sibs and unfamiliar nonsibs. ${ }^{a}$ Compared using binomial tests; ${ }^{b}$ Compared using Wilcoxon signed ranks test. Fisher's procedure of combining probabilities for overall result: $-2 \sum \ln p=20.20, \chi_{(10)} p>0.05$ (number data); $-2 \sum \ln p=25.74$, $\chi_{(10)} p>0.05$ (time data). *Significantly different.

\begin{tabular}{|c|c|c|c|c|}
\hline \multirow[t]{2}{*}{ Parental line } & \multicolumn{2}{|c|}{ Number spending most time near ${ }^{\mathrm{a}}$} & \multicolumn{2}{|c|}{ Time spent in zones ${ }^{b}($ Mean $\pm S E)$} \\
\hline & Familiar sibs & $\begin{array}{c}\text { Unfamiliar } \\
\text { non-sibs }\end{array}$ & $\begin{array}{l}\text { Familiar } \\
\text { sibs }\end{array}$ & $\begin{array}{c}\text { Unfamiliar } \\
\text { non-sibs }\end{array}$ \\
\hline $\mathrm{P}_{1}$ & 19 & 11 & $337.07 \pm 30.41$ & $262.93 \pm 30.41$ \\
\hline $\mathrm{P}_{2}$ & 18 & 12 & $370.03 \pm 39.02$ & $229.96 \pm 39.02$ \\
\hline $\mathrm{P}_{3}$ & $22^{*}$ & 8 & $371.73 \pm 23.11^{*}$ & $228.26 \pm 23.11$ \\
\hline $\mathrm{P}_{4}$ & 18 & 12 & $332.50 \pm 33.50$ & $267.50 \pm 33.50$ \\
\hline $\mathrm{P}_{5}$ & 20 & 10 & $379.03 \pm 33.97^{*}$ & $220.96 \pm 33.97$ \\
\hline
\end{tabular}

Table 3. Association preference of Hylarana temporalis tadpoles (Stage 28-30) with unfamiliar sibs and familiar nonsibs. ${ }^{a}$ Compared using binomial tests; ${ }^{b}$ Compared using Wilcoxon signed ranks test. Fisher's procedure of combining probabilities for overall result: $-2 \sum \ln p=17.60, \chi_{(10)} p>0.05$ (number data); $-2 \sum \ln p=20.86$, $\chi_{(10)} p>0.05$ (time data). *Significantly different.

\begin{tabular}{|c|c|c|c|c|}
\hline \multirow[t]{2}{*}{ Parental line } & \multicolumn{2}{|c|}{ Number spending most time near ${ }^{\mathrm{a}}$} & \multicolumn{2}{|c|}{ Time spent in zones ${ }^{b}($ Mean \pm SE) } \\
\hline & Unfamiliar sibs & $\begin{array}{l}\text { Familiar } \\
\text { non-sibs }\end{array}$ & $\begin{array}{l}\text { Unfamiliar } \\
\text { sibs }\end{array}$ & $\begin{array}{l}\text { Familiar } \\
\text { non-sibs }\end{array}$ \\
\hline$P_{1}$ & 7 & 3 & $377.10 \pm 45.53$ & $222.90 \pm 45.53$ \\
\hline $\mathrm{P}_{2}$ & 8 & 2 & $378.70 \pm 59.30$ & $221.30 \pm 59.30$ \\
\hline $\mathrm{P}_{3}$ & 7 & 3 & $370.50 \pm 37.06$ & $229.50 \pm 37.06$ \\
\hline $\mathrm{P}_{4}$ & 8 & 2 & $380.80 \pm 33.03^{*}$ & $219.20 \pm 33.03$ \\
\hline $\mathrm{P}_{5}$ & 8 & 2 & $354.70 \pm 56.93$ & $245.70 \pm 56.93$ \\
\hline
\end{tabular}

Table 4. Association preference of Hylarana temporalis tadpoles (Stage 28-30) with unfamiliar sibs and unfamiliar non-sibs. ${ }^{a}$ Compared using binomial tests; ${ }^{b}$ Compared using Wilcoxon signed ranks test. Fisher's procedure of combining probabilities for overall result: $-2 \sum \ln p=44.56, \chi_{(10)} p>0.05$ (number data); $-2 \sum \ln p=43.24$, $\chi_{(10)} p>0.05$ (time data). Significantly different.

\begin{tabular}{|c|c|c|c|c|}
\hline \multirow[t]{2}{*}{ Parental line } & \multicolumn{2}{|c|}{ Number spending most time near } & \multicolumn{2}{|c|}{ Time spent in zones ${ }^{b}($ Mean $\pm S E)$} \\
\hline & Unfamiliar sibs & $\begin{array}{c}\text { Unfamiliar } \\
\text { non-sibs }\end{array}$ & $\begin{array}{l}\text { Unfamiliar } \\
\text { sibs }\end{array}$ & $\begin{array}{c}\text { Unfamiliar } \\
\text { non-sibs }\end{array}$ \\
\hline$P_{1}$ & $9 *$ & 1 & $468.00 \pm 50.71^{*}$ & $132.00 \pm 50.71$ \\
\hline $\mathrm{P}_{2}$ & $10^{*}$ & 0 & $537.90 \pm 26.20^{*}$ & $62.10 \pm 26.20$ \\
\hline $\mathrm{P}_{3}$ & $9 *$ & 1 & $484.90 \pm 59.19^{*}$ & $115.20 \pm 59.19$ \\
\hline $\mathrm{P}_{4}$ & $10^{*}$ & 0 & $511.20 \pm 37.58^{*}$ & $88.80 \pm 37.58$ \\
\hline $\mathrm{P}_{5}$ & 8 & 2 & $407.60 \pm 37.22^{*}$ & $192.40 \pm 37.22$ \\
\hline
\end{tabular}


Table 5. Association preference of Hylarana temporalis tadpoles (Stage 28-30) with familiar sibs and unfamiliar sibs. ${ }^{a}$ Compared using binomial tests; ${ }^{b}$ Compared using Wilcoxon signed ranks test. Fisher's procedure of combining probabilities for overall result: $-2 \sum \ln p=5.40, \chi_{(10)} p>0.05$ (number data); $-2 \sum \ln p=6.42$, $\chi_{(10)} p>0.05$ (time data).

\begin{tabular}{|c|c|c|c|c|}
\hline \multirow[t]{2}{*}{ Parental line } & \multicolumn{2}{|c|}{ Number spending most time near } & \multicolumn{2}{|c|}{ Time spent in zones ${ }^{b}($ Mean $\pm S E)$} \\
\hline & Familiar sibs & $\begin{array}{l}\text { Unfamiliar } \\
\text { sibs }\end{array}$ & $\begin{array}{l}\text { Familiar } \\
\text { sibs }\end{array}$ & $\begin{array}{l}\text { Unfamiliar } \\
\text { sibs }\end{array}$ \\
\hline $\mathrm{P}_{1}$ & 7 & 3 & $342.80 \pm 54.23$ & $257.20 \pm 54.23$ \\
\hline $\mathrm{P}_{2}$ & 6 & 4 & $339.10 \pm 58.32$ & $260.90 \pm 58.32$ \\
\hline $\mathrm{P}_{3}$ & 7 & 3 & $326.40 \pm 58.14$ & $273.60 \pm 58.14$ \\
\hline $\mathrm{P}_{4}$ & 6 & 4 & $317.10 \pm 52.21$ & $282.90 \pm 52.21$ \\
\hline $\mathrm{P}_{5}$ & 5 & 5 & $315.40 \pm 68.21$ & $284.60 \pm 68.21$ \\
\hline
\end{tabular}

Table 6. Distribution of Hylarana temporalis tadpoles (Stage 34-36) in end-bias test. a Compared using binomial tests; ${ }^{b}$ Compared using Wilcoxon signed ranks test. Fisher's procedure of combining probabilities for overall result: $-2 \sum \ln p=1.04, \chi_{(10)} p>0.05$ (number data); $-2 \sum \ln p=2.46, \chi_{(10)} p>0.05$ (time data).

\begin{tabular}{|c|c|c|c|c|}
\hline \multirow[t]{2}{*}{ Parental line } & \multicolumn{2}{|c|}{ Number spending most time near } & \multicolumn{2}{|c|}{ Time spent in zones ${ }^{b}($ Mean $\pm S E)$} \\
\hline & Zone A & Zone B & Zone A & Zone B \\
\hline$P_{1}$ & 9 & 11 & $304.55 \pm 42.26$ & $295.45 \pm 42.26$ \\
\hline $\mathrm{P}_{2}$ & 10 & 10 & $248.94 \pm 28.02$ & $351.05 \pm 28.02$ \\
\hline $\mathrm{P}_{3}$ & 9 & 11 & $295.50 \pm 30.61$ & $304.50 \pm 30.61$ \\
\hline $\mathrm{P}_{4}$ & 11 & 9 & $301.15 \pm 36.78$ & $298.85 \pm 36.78$ \\
\hline $\mathrm{P}_{5}$ & 10 & 10 & $301.80 \pm 22.82$ & $298.00 \pm 22.82$ \\
\hline
\end{tabular}

Table 7. Association preference of Hylarana temporalis tadpoles (Stage 34-36) with familiar sibs and unfamiliar nonsibs. ${ }^{a}$ Compared using binomial tests; ${ }^{b}$ Compared using Wilcoxon signed ranks test. Fisher's procedure of combining probabilities for overall result: $-2 \sum \ln p=7.82, \chi_{(10)} p>0.05$ (number data); $-2 \sum \ln p=12.68$, $\chi_{(10)} p>0.05$ (time data).

\begin{tabular}{|c|c|c|c|c|}
\hline \multirow[t]{2}{*}{ Parental line } & \multicolumn{2}{|c|}{ Number spending most time near ${ }^{a}$} & \multicolumn{2}{|c|}{ Time spent in zones $^{b}($ Mean \pm SE) } \\
\hline & Familiar sibs & $\begin{array}{c}\text { Unfamiliar } \\
\text { non-sibs }\end{array}$ & $\begin{array}{l}\text { Familiar } \\
\text { sibs }\end{array}$ & $\begin{array}{l}\text { Unfamiliar } \\
\text { non-sibs }\end{array}$ \\
\hline $\mathrm{P}_{1}$ & 11 & 19 & $218.83 \pm 36.80$ & $381.16 \pm 36.80$ \\
\hline $\mathrm{P}_{2}$ & 14 & 16 & $289.86 \pm 30.72$ & $310.13 \pm 30.72$ \\
\hline $\mathrm{P}_{3}$ & 16 & 14 & $293.26 \pm 26.82$ & $306.73 \pm 26.82$ \\
\hline $\mathrm{P}_{4}$ & 18 & 12 & $350.70 \pm 40.03$ & $249.30 \pm 40.03$ \\
\hline $\mathrm{P}_{5}$ & 18 & 12 & $333.23 \pm 32.72$ & $266.76 \pm 32.72$ \\
\hline
\end{tabular}


Table 8. Distribution of tadpoles of Sphaerotheca breviceps (Stage 28-30) in end-bias test. ${ }^{\mathrm{a} C o m p a r e d ~ u s i n g ~ b i n o m i a l ~}$ tests; ${ }^{b}$ Compared using Wilcoxon signed ranks test. Fisher's procedure of combining probabilities for overall result: $-2 \sum \ln p=2.14, \chi_{(08)} p>0.05$ (number data); $-2 \sum \ln p=6.90, \chi_{(08)} p>0.05$ (time data).

\begin{tabular}{|c|c|c|c|c|}
\hline \multirow[t]{2}{*}{ Parental line } & \multicolumn{2}{|c|}{ Number spending most time near ${ }^{\mathrm{a}}$} & \multicolumn{2}{|c|}{ Time spent in zones ${ }^{b}($ Mean \pm SE) } \\
\hline & Zone A & Zone B & Zone A & Zone B \\
\hline$P_{1}$ & 12 & 8 & $321.40 \pm 51.17$ & $278.60 \pm 51.17$ \\
\hline $\mathrm{P}_{2}$ & 11 & 9 & $291.30 \pm 35.81$ & $308.70 \pm 35.81$ \\
\hline $\mathrm{P}_{3}$ & 11 & 9 & $339.65 \pm 36.47$ & $260.35 \pm 36.47$ \\
\hline $\mathrm{P}_{4}$ & 10 & 10 & $301.25 \pm 39.64$ & $298.75 \pm 39.64$ \\
\hline
\end{tabular}

Table 9. Distribution of tadpoles of Sphaerotheca breviceps (Stage 34-36) in end-bias test. ${ }^{a}$ Compared using binomial tests; ${ }^{b}$ Compared using Wilcoxon signed ranks test. Fisher's procedure of combining probabilities for overall result: $-2 \sum \ln p=3.06, \chi_{(08)} p>0.05$ (number data); $-2 \sum \ln p=5.22, \chi_{(08)} p>0.05$ (time data).

\begin{tabular}{|c|c|c|c|c|}
\hline \multirow[t]{2}{*}{ Parental line } & \multicolumn{2}{|c|}{ Number spending most time near } & \multicolumn{2}{|c|}{ Time spent in zones ${ }^{b}($ Mean $\pm S E)$} \\
\hline & Zone A & Zone B & Zone A & Zone B \\
\hline$P_{1}$ & 11 & 9 & $260.95 \pm 46.28$ & $339.05 \pm 46.28$ \\
\hline $\mathrm{P}_{2}$ & 13 & 7 & $332.30 \pm 32.24$ & $267.70 \pm 32.24$ \\
\hline $\mathrm{P}_{3}$ & 10 & 10 & $334.45 \pm 41.80$ & $265.55 \pm 41.80$ \\
\hline $\mathrm{P}_{4}$ & 10 & 10 & $313.40 \pm 48.99$ & $286.60 \pm 48.99$ \\
\hline
\end{tabular}

Table 10. Association preference of Sphaerotheca breviceps tadpoles (Stage 28-30) with familiar sibs and unfamiliar non-sibs. ${ }^{a}$ Compared using binomial tests; ${ }^{b}$ Compared using Wilcoxon signed ranks test. Fisher's procedure of combining probabilities for overall result: $-2 \sum \ln p=6.44, \chi_{(08)} p>0.05$ (number data); $-2 \sum \ln p=6.90$, $\chi_{(08)} p>0.05$ (time data).

\begin{tabular}{|c|c|c|c|c|}
\hline \multirow[t]{2}{*}{ Parental line } & \multicolumn{2}{|c|}{ Number spending most time near } & \multicolumn{2}{|c|}{ Time spent in zones ${ }^{b}($ Mean $\pm S E)$} \\
\hline & Familiar sibs & $\begin{array}{c}\text { Unfamiliar } \\
\text { non-sibs }\end{array}$ & $\begin{array}{l}\text { Familiar } \\
\text { sibs }\end{array}$ & $\begin{array}{c}\text { Unfamiliar } \\
\text { non-sibs }\end{array}$ \\
\hline $\mathrm{P}_{1}$ & 19 & 11 & $362.56 \pm 38.19$ & $237.43 \pm 38.19$ \\
\hline $\mathrm{P}_{2}$ & 15 & 15 & $281.63 \pm 32.19$ & $318.36 \pm 32.19$ \\
\hline $\mathrm{P}_{3}$ & 19 & 11 & $294.10 \pm 29.76$ & $305.90 \pm 29.76$ \\
\hline $\mathrm{P}_{4}$ & 15 & 15 & $280.06 \pm 39.98$ & $319.93 \pm 39.98$ \\
\hline
\end{tabular}


Table 11. Association preference of Sphaerotheca breviceps tadpoles (Stage 34-36) with familiar sibs and unfamiliar non-sibs. ${ }^{a}$ Compared using binomial tests; ${ }^{b}$ Compared using Wilcoxon signed ranks test. Fisher's procedure of combining probabilities for overall result: $-2 \sum \ln p=5.48, \chi_{(08)} p>0.05$ (number data); $-2 \sum \ln p=6.92$, $\chi_{(08)} p>0.05$ (time data).

\begin{tabular}{lccccc}
\hline Parental line & \multicolumn{2}{c}{ Number spending most time near $^{\mathbf{a}}$} & & \multicolumn{2}{c}{ Time spent in zones $^{\mathbf{b}}$ (Mean \pm SE) } \\
\cline { 2 - 3 } \cline { 5 - 6 } & Familiar sibs & $\begin{array}{c}\text { Unfamiliar } \\
\text { non-sibs }\end{array}$ & & $\begin{array}{c}\text { Familiar } \\
\text { sibs }\end{array}$ & $\begin{array}{c}\text { Unfamiliar } \\
\text { non-sibs }\end{array}$ \\
\hline$P_{1}$ & 12 & 18 & & $258.33 \pm 35.85$ & $341.66 \pm 35.85$ \\
$P_{2}$ & 18 & 12 & & $337.56 \pm 28.77$ & $262.43 \pm 28.77$ \\
$P_{3}$ & 14 & 16 & & $307.43 \pm 37.34$ & $292.56 \pm 37.34$ \\
$P_{4}$ & 17 & 13 & & $302.06 \pm 39.12$ & $297.93 \pm 39.12$ \\
\hline
\end{tabular}

Waldman 1992). True to this assumption, tadpoles of B. americanus, B. melanostictus, $R$. cascadae and $R$. sylvatica that form persistent and compact aggregations throughout larval development exhibit kin discrimination ability throughout their development (Blaustein and Waldman 1992, Saidapur and Girish 2000). In contrast, the tadpoles of $R$. aurora and B. scaber exhibit kin discrimination behavior only during early stages of development when they live in aggregation (Blaustein and Waldman 1992, Gramapurohit et al. 2006) but seemingly lose the ability of kin discrimination later in the development when aggregations are absent. Our results in present study on kin discrimination in tadpoles of $H$. temporalis are comparable to that reported in $R$. aurora and B. scaber. Tadpoles of $H$. temporalis form small aggregations in early stages of development while inhabiting gently flowing stream waters. Perhaps, living with kin is more beneficial in early stages of development in flowing waters where there is no threat of desiccation. If so, it explains the significance of kin discrimination behavior seen in early development in tadpoles of $H$. temporalis. However, with the advancement of dry season, the streams of Western Ghats start drying up locking the tadpoles (often mixed parentage) in water pools isolated from the main stream. At this point tadpoles of $H$. temporalis change their social behavior and live scattered rather than aggregated, and in such small water pockets they begin to face desiccation threat as well as intra -specific competition. Under the changed ecological conditions, priority may be for rapid development and completion of metamorphosis. If so, the strategy would be to avoid energy expenditure on maintaining kin discrimination systems and diverting the same to processes like rapid development of the body and shortening the larval period. Alternatively, under very strong selection to escape drying ponds, competing less with kin for the resources needed to develop, or reducing aggression with kin, would come at too strong a cost to individual performance and fitness, flipping the cost and benefits of Hamilton's rule.

The present study reveals no kin discrimination behavior in early or later stages of development in tadpoles of $S$. breviceps, which do not exhibit aggregations, and completing metamorphosis in rain-filled puddles. In such a 
situation desiccation threat persists throughout development if intermittent rains fail to arrive. A previous study on $S$. breviceps tadpoles (Gramapurohit et al. 2004) has shown that rearing with sibs or non-sibs has no influence on growth and larval duration in this species, implying kinship has no influence on larval growth and development unlike in $H$. temporalis (Girish and Saidapur 1999, 2003). Possibly, in tadpoles of $S$. breviceps that complete growth and metamorphosis in the face of desiccation risk, selection may have favoured rapid growth and metamorphosis in both kin and non-kin environments. This view is supported by the present study where we found no evidence of kin discrimination behavior in tadpoles of $S$. breviceps throughout larval development.

In summary, tadpoles of $H$. temporalis living in small aggregations in streams during early stages of development with no obvious threat of desiccation, exhibit kin discrimination behavior. However, they either lose or simply do not show kin discrimination behavior in their advanced stages of development when they begin to face risks of desiccation due to receding water levels. In contrast, tadpoles of $S$. breviceps complete metamorphosis in puddles under perpetual threat of desiccation and as a consequence might not have evolved kin discrimination behavior. The present findings support the view that kin discrimination behavior in tadpoles may evolve: 1) in relation to their social habits and 2) hydroperiod of the water bodies in which they complete metamorphosis.

\section{Acknowledgments}

APR is thankful to University Grants Commission, New Delhi for financial assistance under SAP-DRS-II program. BAS and SKS thank INSA, New Delhi for support. The work was conducted with approval from CPCSEA, New Delhi under registration No. 639/02/a/ CPCSEA.

\section{References}

Blaustein, A. R. 1987. Kin recognition in vertebrates (excluding primates): empirical evidence. Pp. 287-331 in D. J. C. Fletcher and C. D. Michener (eds.), Kin Recognition in Animals. Chichester, John Wiley and Sons.

Blaustein, A. R. 1988. Ecological correlates and potential functions of kin recognition and kin association in anuran larvae. Behavior Genetics 18: 449-463.

Blaustein, A. R. and S. C. Walls. 1995. Aggregation and kin recognition. Pp. 568-602 in H. Heatwole (ed.), Amphibian Biology, vol. 2, Social Behaviour. Clipping Norton. Surrey Beaty and Sons.

Blaustein, A. R. and B. Waldman. 1992. Kin recognition in anuran amphibians. Animal Behaviour 44: 207-221.

Blaustein, A. R., R. K. O’Hara, and D. H. Olson. 1984. Kin preference behaviour is present after metamorphosis in Rana cascadae frogs. Animal Behaviour 32: 415-450.

Blaustein, A. R., T. Yoshikawa, K. Asoh, and S. C. Walls. 1993. Ontogenetic shifts in tadpole kin recognition: loss of signal and perception. Animal Behaviour 46: $525-538$.

Dudley, S. A., G. P. Murphy, and A. L. File. 2013. Mechanism of plant competition - kin recognition and competition in plants. Functional Ecology 27: 898-906.

Fishwild, T. G., R. A. Schemidt, K. M. Jankens, K. A. Breven, G. J. Gamboa, and C. M. Richard. 1990. Sibling recognition by larval frogs (Rana pipiens, Rana sylvatica and Pseudacris crucifer). Journal of Herpetology 24: 40-44.

Girish, S. and S. K. Saidapur. 1999. The effects of kinship and density on growth and metamorphosis of bronze frog (Rana temporalis) tadpoles. Acta Ethologica 2: 61-66.

Girish, S. and S. K. Saidapur. 2003. Density-dependent growth and metamorphosis in the larval bronze frog Rana temporalis influenced by genetic relatedness of the cohort. Journal of Bioscience 28: 489-496.

Gramapurohit, N. P., D. K. Veeranagoudar, B. A. Shanbhag, and S. K. Saidapur. 2004. Relative influence of kinship and density on metamorphic traits of Tomopterna breviceps. Journal of Herpetology 38: 594-599.

Gramapurohit, N. P., D. K. Veeranagoudar, S. V. Mulkeegoudra, B. A. Shanbhag, and S. K. Saidapur. 2006. Kin recognition in Bufo scaber tadpoles: ontogenetic changes and mechanism. Journal of Ethology 24: 267-274. 
Gramapurohit, N. P., B. A. Shanbhag, and S. K. Saidapur. 2008. Kinship influences larval growth and metamorphic traits of Bufo scaber in a context dependent manner. Journal of Herpetology 42: 39-45.

Gray, H. M., K. Summers, and I. D. Roberto. 2009. Kin discrimination in cannibalistic tadpoles of the green poison frog, Dendrobates auratus (Anuran, Dendrobatidae). Phyllomedusa 8: 41-50.

Gutierrez-C., P. D. A. 2006. Smilisca phaeota (Cope, 1862) (Anura: Hylidae) tadpoles do not discriminate between siblings and non-siblings. Actual Biology 85: 171-177.

Ha, R. R., P. Bentzen, J. Marsh, and J. C. Ha. 2003. Kinship and association in social foraging Northwestern crows (Corvus caurinus). Bird Behaviour 15: 65-75.

Hamilton, W. G. 1964a. The genetical evolution of social behaviour. I. Journal of Theoretical Biology 7: 1-16.

Hamilton, W. G. 1964b. The genetical evolution of social behaviour. II. Journal of Theoretical Biology 7: 17-52.

Harris, R. N., T. J. Vess, J. I. Hammond, and C. J. Lindermuth. 2003. Context-dependent kin discrimination in larval four toed salamanders Hemidactylium scutatum (Caudata: Plethodontidae). Herpetologica 59: 164-177.

Hepper, P. G. 1991. Kin Recognition. Cambridge. Cambridge University Press. 455 pp.

Hokit, D. G., S. C. Walls, and A. R. Blaustein. 1996. Context-dependent kin discrimination in larvae of the marbled salamander, Ambystoma opacum. Animal Behaviour 52: 17-31.

Hokit, D. G. and A. R. Blaustein. 1997. The effects of kinship on interactions between tadpoles of Rana cascadae. Ecology 78: 1722-1735.

Holmes, W. G. 2004. The early history of Hamiltonian-based research on kin recognition. Annales Zoologici Fennici 41: 691-711.

Martin, R. A. and S. C. Garnett. 2013. Relatedness and resource diversity interact to influence the intensity of competition. Biological Journal of the Linnaean Society 110: 687-695.

Mateo, J. M. 2002. Kin-recognition abilities and nepotism as a function of sociality. Proceedings of the Royal Society London 269: 721-727.
Nicieza, A. G. 1999. Context-dependent aggregation in common frog Rana temporaria tadpoles: influence of developmental stage, predation risk and social environment. Functional Ecology 13: 852-858.

O'Hara, R. K. and A. R. Blaustein. 1988. Hyla regilla and Rana pretiosa tadpoles fail to display kin recognition behavior. Animal Behaviour 36: 946-948.

Pakkasmaa, S. and A. Laurila. 2004. Are the effects of kinship modified by environmental conditions in Rana temporaria tadpoles? Annales Zoologici Fennici 41: 413-420.

Pfenning, D. W. and P. W. Sherman. 1995. Kin recognition. Scientific American 272: 98-103.

Pfenning, D. W., J. P. Collins, and R. E. Ziemba. 1999. A test of alternative hypotheses for kin recognition in cannibalistic tiger salamanders. Behavioral Ecology 10: 436-443.

Rajput, A. P., B. A. Shanbhag, and S. K. Saidapur. 2011. Absence of kin discrimination in cannibalistic anuran tadpoles of the frog Hoplobatrachus tigerinus (Daudin). Indian Journal of Experimental Biology 49: 362-365.

Roberts, G. 1996. Why individual vigilance declines as group size increases? Animal Behaviour 51: 1077-1086.

Roche, J. P. 1993. The benefits of kin recognition in tadpoles: a review of the literature. Maine Naturalist 1: 13-20.

Saidapur, S. K. and S. Girish. 2000. The ontogeny of kin recognition in tadpoles of the toad Bufo melanostictus (Anura; Bufonidae). Journal of Bioscience 25: 267-273.

Sokal, R. R. and F. J. Rolf. 1995. Biometry. The Principles and Practice of Statistics in Biological Research. New York. W. H. Freeman and Company. 887 pp.

Waldman, B. 2005. Kin recognition in amphibians. Pp. 162-219 in P. G. Hepper (ed.), Kin Recognition. Cambridge. Cambridge University Press.

Waldman, B. and K. Adler. 1979. Toad tadpoles associate preferentially with siblings. Nature 282: 611-613.

Waldman, B. and P. Bateson. 1989. Kin association in Japanese Quail chicks. Ethology 80: 283-291. 